\title{
PEMBELAJARAN KETERAMPILAN BERBICARA BERBASIS TEKS BIOGRAFI PADA KELAS INKLUSI BERDASARKAN KURIKULUM 2013 (STUDI KASUS DI SMAN 8 SURAKARTA)
}

\author{
Gilang Jaka Sanjaya, Muhammad Rohmadi, Purwadi \\ Universitas Sebelas Maret \\ Surel: gilangjakasanjaya@gmail.com
}

\begin{abstract}
Abstrak: Penelitian ini merupakan penelitian studi kasus. Teknik pengambilan sampel dengan purposive sampling. Sumber data yang digunakan berupa peristiwa, informan, dan dokumen. Teknik pengumpulan data dilakukan dengan observasi, wawancara, dan analisis data. Uji validitas data yang digunakan adalah triangulasi sumber, triangulasi metode, dan review informan. Taknik analisis data yang digunakan adalah model analisis interaktif. Hasil penelitian ini adalah deskripsi tentang: (1) komponen RPP yang disusun oleh guru sesuai dengan Permendikbud, namun kesesuaian isi belum dapat dikatakan baik; (2) pelaksanaan pembelajaran keterampilan berbicara berbasis teks biografi di kelas inklusi SMAN 8 Surakarta telah dilakukan berdasarkan kurikulum 2013; (3) evaluasi yang dilakukan oleh guru mata pelajaran berupa pemberian soal-soal remidi;(4) kendala yang dihadapi guru mata pelajaran bahasa Indonesia pada pembelajaran teks biografi di SMAN 8 Surkarta. Kendala guru meliputi (a) kurangnya pemahaman mengenai bahasa isyarat untuk berkomunikasi dengan siswa berkebutuhan khusus tunadaksa wicara; (b) tidak ada guru pendamping khusus untuk ABK; (c) siswa berkebutuhan khusus cenderung menutup diri, dan (d) kurangnya penggunaan media gambar sebagai media pembelajaran. (5) upaya yang dilakukan guru bahasa Indonesia SMAN 8 Surakarta dalam mengatasi permasalahan yang dihadapi pada pembelajaran teks biografi di kelas inklusi.
\end{abstract}

Kata kunci: teks biografi, inklusi, kelas X

\section{SKILL LEARNING SPEAKING BASED BIOGRAPHIC TEXT IN INCLUSION CLASS BASED ON CURRICULUM 2013 (CASE STUDY IN SMAN 8 SURAKARTA)}

\begin{abstract}
This research is a case study research. The sampling technique was purposive sampling. Data sources used are events, informants and documents. Data collection techniques are carried out by observation, interviews, and data analysis. Data validity test used is source triangulation, method triangulation, and informant review. The data analysis technique used is an interactive analysis model. The results of this study are descriptions of: (1) RPP components prepared by teachers in accordance with Permendikbud, but the conformity of the contents can not be said either; (2) the implementation of biographical text-based speech-learning in the inclusion class of SMAN 8 Surakarta has been conducted based on the 2013 curriculum; (3) evaluations conducted by subject teachers in the form of giving remedial questions; (4) obstacles faced by Indonesian subject teachers in learning biographical texts at SMAN 8 Surkarta. Teacher constraints include (a) lack of understanding of sign language to communicate with students with special needs for quadriplegic speech; (b) there is no special teacher for $A B K$; (c) students with special needs tend to close themselves, and (d) lack of use of the media as a medium of learning media. (5) efforts made by Indonesian language teachers at SMAN 8 Surakarta in addressing the problems faced in learning biographical texts in the inclusive class.
\end{abstract}

Keywords: biographical text, inclusion, class $X$

Keywords: biography text, inclusion, class $X$ 


\section{PENDAHULUAN}

Bahasa merupakan suatu alat komunikasi yang digunakan oleh manusia dalam kehidupannya sehari-hari. Manusia tidak bisa lepas dari aktivitas berkomunikasi. Oleh karena itu, bahasa mempunyai peran yang signifikan bagi kehidupan manusia. Mudjia Rahardjo (dalam Rusdiarti, 2003: 34) mengatakan bahwa manusia memerlukan interaksi dengan pihak lain. Dalam konteks inilah bahasa memainkan peran penting, karena melalui bahasa manusia dapat berkomunikasi dalam interaksinya dengan orang lain. Bahasa adalah sesuatu yang sangat sulit, untuk tidak mengatakan mustahil, dilakukan jika manusia dalam berinteraksi dan berkomunikasi tanpa melibatkan unsur bahasa. Tidak berlebihan apabila fungsi utama bahasa adalah sebagai alat komunikasi di samping juga memainkan fungsi-fungsi lainnya.

Identitas seseorang atau jati diri seseorang dapat dilihat dari bahasa yang mereka gunakan. Bahasa digunakan oleh sejumlah orang yang memiliki beraneka ragam latar belakang, status sosial, usia, asal tinggal, dan lain-lain. Dari pulau Jawa, Kalimantan hingga Papua memiliki bahasa yang berbeda-beda. Dalam hal ini bahasa Indonesia berfungsi sebagai bahasa pemersatu bangsa. Menuurut Chaer , dengan bahasa seseorang dapat menyampaikan pikiran, gagasan, konsep dan juga perasaannya baik secara lisan maupun tulis kepada orang lain. Dalam berbahasa Indonesia, masyarakat Indonesia secara tidak langsung dituntut untuk menggunakan sejumlah keterampilan berbahasa dalam penyampaian pikiran, gagasan, konsep, ide, dan perasaan. Dalam bahasa Indonesia terdapat empat keterampilan yang perlu dikuasai yakni menyimak, berbicara, membaca, dan menulis (Rahmawati, 2003: 30).

Empat keterampilan berbahasa Indonesia tersebut menjadi kompetensi yang dipelajari di pendidikan sekolah menengah atas dan sederajat. Hal tersebut juga dimuat dalam silabus pembelajaran bahasa Indonesia kurikulum 2013. Pembelajaran Bahasa Indonesia dalam Kurikulum 2013 menerapkan pembelajaran berbasis teks yang didasarkan pada prinsip: bahasa dipandang sebagai teks, pemilihan bentuk kebahasaan untuk mengungkapkan makna, bahasa bersifat fungsional, dan bahasa merupakan sarana pembentukan kemampuan berpikir. Bahasa Indonesia dipandang sebagai wahana untuk mengekspresikan pemikiran, baik secara lisan maupun tulisan.

Keterampilan berbicara adalah salah satu keterampilan berbahasa Indonesia yang dimuat dalam silabus pendidikan menengah atas dan sederajat. Berbicara mempunyai peranan sosial yang sangat penting dalam pembelajaran bahasa Indonesia. Tujuan berbicara adalah untuk menyampaikan informasi kepada orang lain dengan bahasa lisan. Seperti peserta didik yang membacakan teks biografi di depan kelas guna menyampaikan informasi mengenai sejarah seorang tokoh, pelajaran yang dapat diambil dari kehidupan tokoh, dan lain sebagainya.

Berkenaan dengan itu, fungsi membaca teks biografi dalam pembelajaran bahasa Indonesia adalah pembentukan karakter yang kuat. Pembelajaran bahasa yang disajikan dalam bentuk pengajaran teks biografi ini memungkinkan pembentukan karakter manusia atau peserta didik untuk meningkatan kemampuan berpikir, mengungkapkan gagasan, penyampaian informasi tentang suatu peristiwa dan kemampuan untuk memperluas wawasan.

Pembelajaran teks biografi harus memenuhi ciri khas sebuah pembelajaran pada umumnya. Pembelajaran merupakan kegiatan mentransfer pengetahuan atau interaksi dari berbagai komponen. Pembelajaran merupakan sebuah sistem. Berhasil atau tidaknya pembelajaran ditentukan oleh berbagai komponen yang terlibat dalam pembelajaran tersebut. Komponen-komponen tersebut adalah guru, peserta didik, tujuan pembelajaran, 
evaluasi, dan sarana yang dibutuhkan dalam proses atau kegiatan pembelajaran.

Undang-undang Dasar 1945

menyebutkan bahwa tujuan pendidikan Indonesia adalah mencerdaskan kehidupan bangsa. Oleh karena itu pembelajaran harus selalu berkembang dan berkaitan dengan sistem pendidikan. Suasana lingkungan belajar, media dan sarana pembelajaran, serta penunjang pembelajaran lainnya yang tidak membedakan selalu diimplementasikan dalam pendidikan Indonesia dengan tujuan memperbaiki sistem pendidikan secara keseluruhan.

Pendidikan merupakan hak bagi setiap warga negara. Pendidikan tidak memandang latar belakang, usia, status, dan kondisi fisik warga negara. Semua warga negara Indonesia berhak mendapatkan pembelajaran yang layak dan adil. Pendidikan berfungsi sebagai langkah untuk menjadikan warga negara Indonesia bermartabat dan berkarakter kuat, sehingga mampu untuk berkembang mengikuti era global. Berkenaan dengan hak untuk mendapatkan pendidikan yang bermutu dilaksanakan berdasarkan Undang-Undang Dasar 1945 pasal 31 ayat 1 dan UndangUndang Nomor 20 tahun 2003 tentang Sistem Pendidikan Nasional.

Pendidikan bermutu bukan serta merta berlangsung pada mereka yang berlatar belakang normal. Pendidikan yang bermutu juga harus berlaku pada seluruh warga negara Indonesia tidak terkecuali anak berkebutuhan khusus (ABK). Anak berkebutuhan khusus (ABK) adalah anak yang memiliki kondisi keterbatasan yang lain daripada anak normal lainnya. Anak berkebutuhan khusus (ABK) memiliki hambatan dalam melangsungkan mobilitas kehidupan mereka tidak terkecuali hambata-hambatan dalam proses pembelajaran. Keterbatasan yang mereka miliki yakni keterbatasan fisik, mental, emosional, dan sosial. Berbeda dengan anak normal lainnya, anak berkebutuhan khusus (ABK) memang sejatinya perlu mendapatkan perlakuan dan fasilitas khusus guna mendapatkan pendidikan yang layak dan merata.

Sesuai dengan Peraturan Menteri Pendidikan Nasional Nomor 70 Tahun 2009 tentang Pendidikan Inklusif bagi peserta didik yang memiliki kelainan dan memiliki potensi kecerasan dan atau bakat istimewa, yang dimaksud dengan pendidikan inklusif adalah sistem penyelenggaraan pendidikan yang memberikan kesempatan kepada semua peserta didik yang memiliki kelainan dan memiliki potensi kecerdasan dan atau bakat istimewa untuk mengikuti pendidikan atau pembelajaran dalam lingkungan pendidikan secara bersamasama dengan peserta didik pada umumnya. Setiap peserta didik yang memiliki kelainan fisik, emosional, mental, sosial, atau memiliki potensi kecerdasan dan atau bakat istimewa berhak mengikuti pendidikan secara inklusif pada satuan pendidikan tertentu sesuai dengan kebutuhan dan kemampuannya (Trimo, 2012)

Pendidikan inklusi merupakan upaya yang dilakukan pemerintah untuk pemenuhan kebutuhan anak berkebutuhan khusus (ABK) akan pendidikan. Dengan sistem pendidikan inklusif, anak berkubutuhan khusus (ABK) dapat melangsungkan pembelajaran di kelas dengan lancar yang didukung oleh fasilitas dan layanan yang khusus. Sehingga dengan adanya pendidikan inklusi dapat meratakan mutu pendidikan, dan mereka mendapatkan hak pendidikan yang sama dengan anak normal pada umumnya.

Indonesia saat ini menyelenggarakan sistem pendidikan inklusi dengan melalui tiga lembaga, yakni Sekolah Luar Biasa (SLB), Sekolah Dasar Luar Biasa (SDLB), dan Sekolah Umum. SLB dan SDLB adalah sekolah yang menampung berbagai peserta didik yang berkebutuhan khusus, sedangkan sekolah umum adalah sekolah reguler yang juga menampung anak bekebutuhan khusus dengan kurikulum, guru, sarana pengajaran, dan kegiatan 
belajar mengajar yang disesuaikan dengan kebutuhan peserta didik.

Pemerintah telah memprogram untuk menyediakan pelayanan pendidikan bagi anak berkebutuhan khusus agar mudah untuk diakses dan dicapai. Hal tersebut telah dilakukan pada jenjang sekolah dasar, sekolah menengah umum, dan kejuruan agar senantiasa menerima anak berkebutuhan khusus (ABK) di setiap sekolah yang ditunjuk. Harapannya adalah agar anak berkebutuhan khusus (ABK) dapat menimba ilmu bersama dengan anak lainnya dalam satu ruangan yang sama, tanpa membedakan kondisi fisik, mental, dan emosional.

Salah satu sekolah yang memfasilitasi ABK adalah Sekolah Menengah Atas Negeri 8 Surakarta adalah salah satu sekolah yang ditunjuk pemerintah untuk menerima dan membina anak berkebutuhan khusus (ABK) dalam proses pembelajaran. Penyelenggaraan pembelajaran inklusi di SMAN 8 Surakarta sudah dilakukan, dan adanya kelas khusus dalam proses belajar mengajar diharapkan mampu mencapai tujuan pembelajaran.

SMAN 8 Surakarta merupakan sekolah yang ditunjuk oleh pemerintah untuk menampung dan menimba siswa reguler dan berkebutuhan khusus. Di dalam proses pembelajaran, sebelum pelaksanaannya semestinya guru menyusun rencana pelaksanaan pembelajaran berupa silabus dan RPP. Silabus dan RPP disusun berdasarkan kebutuhan siswa. Dalam hal ini tentu terdapat perbedaan antara RPP untuk siswa reguler dan berkebutuhan khusus. Sama halnya dengan persiapan yang dilakukan, proses kegiatan belajar mengajar dan evaluasi pun semestinya terdapat perbedaan antara siswa reguler dan berkebutuhan khusus. Oleh karenanya sangat menarik untuk dilakukan sebuah penelitian tentang pelaksanaan pembelajaran teks biografi terhadap peserta didik dengan hambatan berbicara.

Berkaitan dengan hal di atas, peniliti tertarik untuk melakukan penelitian mengenai pembelajaran teks biografi pada peserta didik dengan hambatan berbicara. Peneliti tertarik untuk mengetahui perencanaan pembelajaran berupa penyusunan perangkat pembelajaran, proses pelaksanaan pembelajaran, dan proses evaluasi pembelajaran oleh guru terhadap peserta didik dengan hambatan berbicara. Dari uraian tersebut peneliti melakukan penelitian proses pembelajaran dengan judul "Pembelajaran Teks Biografi pada Implementasi Kurikulum 2013 di Kelas Inklusi (Studi Kasus di SMAN 8 Surakarta)".

\section{METODE PENELITIAN}

Pendekatan yang digunakan dalam penelitian ini adalah pendekatan deskriptif kualitatif. Metode yang digunakan dalam penelitian ini adalah studi kasus. Cakupan studi kasus menyelidiki banyak variabel dan banyak kondisi dalam sampel kecil. Penilitian ini akan dilaksanakan pada sampel kecil, yaitu megkaji pembelajaran teks biografi pada peserta didik kelas $\mathrm{X}$ IPS 2 dan X IPS 5 SMAN 8 Surakarta. Langkah dalam penelitian studi kasus menurut Yin (2015: 61) adalah dengan cara (1) menyusun desain penelitian dengan mengembangkan teori dan menghubungkan dengan penelitian terdahulu (2) mengumpulkan data dengan observasi, wawancara dan analisis dokumen (3) analisis data, (4) menyusun laporan.

\section{HASIL DAN PEMBAHASAN}

Pendidikan inklusi adalah solusi terbaik dan strategis untuk melakukan pembelajaran di dalam kelas bagi anak berkebutuhan khusus (ABK). Anak berkebutuhan khusus mendapatkan hak pembelajaran yang layak sesuai dengan kebutuhan peserta didik. Pemberian pembelajaran yang baik bagi anak berkebutuhan khusus dapat dimulai dari perencanaan yang baik, tepat, dan terencana. Perencanaan pembelajaaran tersebut dapat dilakukan oleh guru dan ahli pendidikan terkait. Guru dan ahli 
pendidikan tersebut harus memahami betul kebutuhan-kebutuhan para peserta didik berkebutuhan khusus dan reguler.

\section{Perencanaan}

Pembelajaran

Keterampilan Berbicara Berbasis Teks Biografi di SMAN 8 Surakarta Kelas Inklusi X IPS 2 dan X IPS 5

Pembelajaran teks biografi di SMA merupakan salah satu bentuk cakupan kompetensi pembelajaran bahasa Indonesia yang bertujuan untuk memahami, menceritakan kembali, dan meneladani tokoh dalam sebuah teks biografi. Dalam pelakasanaan pembelajaran teks biografi di kelas inklusi SMAN 8 Surakarta, dilaksanakan pada dua kelas inklusi, yakni kelas X IPS 2 yang berjumlah 29 siswa reguler dan 1 siswa berkebutuhan khusus. Pembelajaran teks biografi juga dilaksanakan di kelas inklusi X IPS 5 yang berjumlah 29 siswa reguler dan 1 siswa berkebutuhan khusus. Siswa atau peserta didik berkebutuhan khusus dan siswa normal atau reguler ditempatkan dalam satu ruangan kelas yang sama dan mengikuti pembelajaran.

Rencana Pelaksanaan Pembelajaran (RPP) adalah rencana yang dibuat oleh pendidik untuk menggambarkan prosedur pembelajaran agar dalam pelaksanaan pembelajaran dapat berjalan secara prosedural dan struktural serta untuk mencapai satu kompetensi dasar yang dijabarkan dari silabus. RPP sudah semestinya disusun dengan memuat kegiatan konkret langkah demi langkah yang dilakukan oleh guru di kelas dalam penyampaian materi juga pendampingan terhadap siswa reguler dan berkebutuhan khusus. Penyusunan rencana pelakasanaan pembelajaran (RPP) tidak dilakukan secara acak tetapi harus berdasarkan kebutuhan peserta didik, dan berfokus pada peserta didik, sedangkan guru hanya berperan sebagai fasilitator dan pendamping. Guru sebagai fasilitator memungkinkan peserta didik tetap aktif dalam kegiatan pembelajaran. Guru dalam menyususn RPP perlu memerhatikan kondisi kelas dan peserta didik dalam memilih pendekatan, metode, media serta materi yang akan digunakan.

Rencana pelaksanaan pembelajaran (RPP) mata pelajaran Bahasa Indonesia tentang pembelajaran teks biografi di kelas $X$ IPS 2 dan kelas $X$ IPS 5 SMAN 8 Surakarta dibuat oleh guru mata pelajaran bahasa Indonesia. Guru mata pelajaran bahasa Indonesia membuat RPP dengan cara mengembangkannya dari silabus yang sudah dibuat oleh tim MGMP Bahasa Indonesia.

Rencana pelakasanaan pembelajaran (RPP) bagi peserta didik berkebutuhan khusus yang dibuat oleh guru mata pelajaran disamakan dengan peserta didik reguler. Perbedaan terletak bukan pada RPP yang dibuat, melainkan saat proses penilaian dan evaluasi yang diberikan oleh guru mata pelajaran. Penyusunan RPP berdasarkan pengembangan dari silabus yang telah disusun oleh tim MGMP Bahasa Indonesia. Kemudian guru mata pelajaran memilih metode dan media yang disesuaikan dengan kebutuhan peserta didik reguler dan berkebutuhan khusus. RPP yang digunakan sebagai pegangan mencakup beberapa komponen di antaranya adalah kompetensi inti, kompetensi dasar, indikator pencapaian kompetensi, tujuan pembelajaran, materi pembelajaran, pendekatan, kegiatan pembelajaran, penilaian remidial dan pengayaan pembelajran dan media/alat sumber pembelajaran.

Kompetensi dasar merupakan kriteria minimal yang harus dikuasai oleh peserta didik dengan menggambarkan penguasaan pengetahuan, sikap, dan keterampilan yang diharapkan dapat dicapai pada setiap kelas pada mata pelajaran bahasa Indonesia. Kompetensi dasar ditentukan oleh guru berdasarkan silabus yang ada. Kompetensi dasar yang digunakan oleh guru N dalam RPP sama dengan kompetensi dasar yang ada pada silabus pembelajaran bahasa Indonesia untuk SMA/SMK/MA/MAK. Salah satu kompetensi dasar untuk kompetensi keterampilan adalah mengungkapkan 
kembali hal-hal yang dapat diteladani dari tokoh yang terdapat dalam teks biografi yang dibaca secara tertulis.

Pencapaian peserta didik yang diukur menggunakan indikator pembelajaran tercantum dalam RPP diharapkan sesuai dengan tujuan pembelajaran. Dalam RPP pembelajaran teks biografi yang telah disusun oleh guru mata pelajaran terdapat beberapa tujuan pembelajaran yaitu siswa diharapkan mampu mengidentifikasi peristiwa dalam biografi tokoh yang dapat diteladani, menggali hal yang dapat diteladani dari teks biografi, menafsirkan hal yang dapat diteladani dari teks biografi, Memproyeksikan kembali hal-hal yang dapat diteladani dari tokoh yang terdapat dalam teks biografi yang dibaca secara tertulis, Menyampaikan kembali hal-hal yang dapat diteladani dari peristiwa yang tertuang dalam dalam teks biografi, dan Memberikan komentar secara lisan atau tulis terhadap hasil kerja teman atau kelompok lain.

Tujuan pembelajaran dapat tercapai apabila guru mata pelajaran dapat menyesuaikan metode pembelajaran yang tepat bagi peserta didik. Dalam RPP yang disusun oleh guru mata pelajaran, metode pembelajaran yang digunakan mencakup konsep dasar (basic concept), pendefinisian masalah (defining the problem), pembelajaran mandiri (self learning), pertukaran pengetahuan (exchange knowledge), dan penilaian (assessment).

Rencana Pelaksanaan Pembelajaran (RPP) juga meliputi materi pembelajaran yang dikembangkan dari buku ajar yang digunakan oleh guru mata pelajaran yang juga disesuaikan dengan media pembelajaran berupa lembar kerja siswa (LKS) dan power point LCD. Pelaksanaan pembelajaran teks biografi dalam RPP yang sudah disusun oleh guru mata pelajaran diawali dari kegiatan stimulus berupa mengajukan pertanyaan-pertanyaan yang mengaitkan pengetahuan sebelumnya dengan materi yang akan dipelajari.
Setelah itu guru menjelaskan tujuan pembelajaran beserta indikator-indokator yang harus dicapai oleh peserta didik. Penyampaian materi disampaikan oleh guru mata pelajaran dengan menggunakan metode dan media pembelajaran yang sudah tersusun dalam RPP.

Pada pembelajaran teks biografi, kegiatan inti yang terdapat di dalam rencana pelaksanaan pembelajaran (RPP) mencakup berbagai aspek yaitu mengamati, menanya, mengeksplorasi, mengasosiasi, dan mengomunikasikan. Dalam kegiatan ini guru mata pelajaran hanya sebagai fasilitator dan pendamping, sedangkan peserta didik harus aktif dan bekerja secara kelompok. Siswa diminta untuk mengamati dari sudut pandang mereka terhadap tokoh dalam biografi, selanjutnya dibebaskan untuk bertanya. Dalam proses mengeksplorasi, peserta didik diminta untuk memproyeksikan kembali hal-hal yang dapat diteladani dari tokoh dalam biografi. Kemudian didiskusikan secara kelompok dan memberikan komentar terhadap tokoh dalam biografi secara lisan di depan kelas.

Pada pembelajaran teks biografi, kegiatan inti yang terdapat di dalam rencana pelaksanaan pembelajaran (RPP) mencakup berbagai aspek yaitu mengamati, menanya, mengeksplorasi, mengasosiasi, dan mengomunikasikan. Dalam kegiatan ini guru $\mathrm{N}$ hanya sebagai fasilitator dan pendamping, sedangkan peserta didik harus aktif dan bekerja secara kelompok. Siswa diminta untuk mengamati dari sudut pandang mereka terhadap tokoh dalam biografi, selanjutnya dibebaskan untuk bertanya. Dalam proses mengeksplorasi, peserta didik diminta untuk memproyeksikan kembali hal-hal yang dapat diteladani dari tokoh dalam biografi. Kemudian didiskusikan secara kelompok dan memberikan komentar terhadap tokoh dalam biografi secara lisan di depan kelas.

Rencana pelaksanaan pembelajaran (RPP) yang disusun guru mata pelajaran mengenai pembelajaran teks biografi 
ditutup dengan kegiatan penutup berupa refleksi untuk mengevaluasi seluruh rangkaian aktivitas pembelajaran dan hasilhasil yang diperoleh untuk selanjutnya secara bersama menemukan manfaat langsung maupun tidak langsung dari hasil pembelajaran yang telah berlangsung, memberikan umpan balik terhadap proses dan hasil pembelajaran, melakukan kegiatan tindak lanjut dalam bentuk pemberian tugas, baik tugas individual maupun kelompok, dan menginformasikan rencana kegiatan pembelajaran untuk peertemuan selanjutnya.

RPP yang dibuat oleh guru mata pelajaran sudah sesuai dengan Permendikbud Nomor 22 Tahun 2016. Komponen yang disusun memiliki keterkaitan dan keterpaduan. Dalam RPP tujuan pembelajaran, kompetensi dasar dan indikator, materi pembelajaran dan penilaian yang disusun berdasarkan silabus yang ada. RPP dikembangkan menyesuaikan kebutuhan peserta didik baik reguler maupun berkebutuhan khusus. Adapun untuk komponen yang lain seperti metode pembelajaran, kegiatan pembelajaran, dan alat/bahan/sumber belajar, disusun guru dengan menambah dari sumber lain dan dengan melihat kondisi peserta didik. Langkah-langkah pembelajaran dituliskan guru mata pelajaran yang meliputi tahap pendahuluan, kegiatan inti, dan penutup telah runtut, namun pada faktanya penerapan langkah-langkah tersebut berbeda. Guru tidak menuliskan secara rinci mengenai proses dan pelaksanaan pembelajaran pada kegiatan inti, guru hanya menuliskan garis besar dari langkah pembelajaran.

Proses Pembelajaran Keterampilan Berbicara Berbasis Teks Biografi di SMAN 8 Surakarta Kelas Inklusi X IPS 2 dan X IPS 5

SMAN 8 Surakarta adalah salah satu sekolah yang mengampu peserta didik berkebutuhan khusus yang berada dalam satu ruangan dengan peserta didik reguler. Kurikulum yang diterapkan adalah kurikulum reguler, yakni K13 atau Kurikulum 2013 yang juga merupakan kurikulum yang diterapkan di sekolah reguler lainnya.

Guru mata pelajaran bahasa Indonesia, memulai kegiatan pembelajaran di masing-masing kelas dengan cara yang sama. Hal pertama yang dilakukan adalah mengondisikan kelas baik dari segi peserta didik maupun kondisi kebersihan kelas. Dalam hal ini guru mata pelajaran bahasa Indonesia meminta peserta didik untuk merapikan meja belajar mereka guna menunjang kenyamanan dalam proses belajar, setelah itu meminta ketua kelas untuk memimpin berdoa ketika jam pembelajaran dimulai pada jam pertama. Berdasarkan RPP yang telah disusun oleh guru mata pelajaran bahasa Indonesia, pemberian stimulus berupa pertanyaanpertanyaan awal mengenai pembelajaran teks biografi juga dilakukan.

K13 atau Kurikulum 2013 menuntut peserta didik untuk lebih aktif, sedangkan guru mata pelajaran sebagai fasilitator dan pendamping. Dalam hal ini dibuktikan dalam kegiatan inti pembelajaran, yang membiarkan peserta didik mengamati, menanya, mengeksplorasi, mengasosiasi, dan mengomunikasikan pembelajaran teks biografi. Dengan penerapan metode seperti itu akan membuat peserta didik lebih aktif dan merangsang rasa ingin tahu dari teks biografi yang mereka pelajari.

Bagian akhir dari sebuah pembelajaran adalah kegiatan penutup. Sesuai dengan RPP, kegiatan penutup dalam pembelajaran teks biografi adalah guru melakukan kegiatan berupa refleksi dan mengevaluasi pembelajaran yang telah berlangsung, pemberian umpan balik terhadap proses dan hasil pembelajaran, pemberian tugas, dan pemberian informasi mengenai pembelajaran yang akan dilaksanakan pada pertemuan yang akan datang.

Berdasarkan observasi yang dilakukan di kelas X IS2 dan X IS5 SMAN 8 Surakarta, ditemukan model pembelajaran inklusi yang diterapkan. 
Model pembelajaran yang dilakukan diikuti oleh peserta didik berkebutuhan khusus yang tergabung dengan peserta didik reguler dalam semua mata pelajaran, termasuk mata pelajaran bahasa Indonesia. Hal ini disebut dengan model penuh. Peserta didik berkebutuhan khusus mengikuti pembelajaran teks biografi di dalam satu ruangan kelas yang sama dengan peserta didik reguler.

Proses pembelajaran teks biografi di dua kelas inklusi yakni X IPS 2 dan X IPS 5 SMAN 8 Surakarta sudah dilaksanakan oleh guru $\mathrm{N}$ sesuai dengan RPP yang disusun. Pelaksanaan pembelajaran teks biografi sudah disesuaikan dengan alokasi yang tercantum dalam RPP. Terkadang dalam proses pembelajaran tidak sesuai dengan alokasi waktu dikarenakan kondisi kelas yang ramai dan sejumlah kendala dari peserta didik berkebutuhan khusus. Selain itu, penyelenggaraan sekolah atau kelas inklusi di SMAN 8 Surakarta sudah sesuai dengan peraturan pemerintah. Penyelenggaraan sekolah inklusi juga menjadi wewenang bagi pemerintah dan sekolah agar menjamin dengan baik dan sesuai dengan kebutuhan masing-masing sekolah. SMAN 8 Surakarta dinilai mampu menjadi sebagai sekolah menengah atas untuk menyelenggarakan sekolah inklusi dan membuat kebijakan sesuai dengan kondisi dan kebutuhan peserta didik juga sekolah.

Model pembelajaran teks biografi di SMAN 8 Surakarta kelas X IPS 2 dan X IPS 5 yang telah dilakukan, menghasilkan sebuah manfaat bagi peserta didik berkebutuhan khusus untuk lebih aktif dalam menemukan nilai-nilai pendidikan, perjuangan, serta hal-hal yang dapat dicontoh dari tokoh dalam teks biografi. Hasil penelitian menunjukkan bahwa model inklusi penuh dan juga kelas besar secara secara heterogen membuat peserta didik berkebutuhan khusus menjadi lebih nyaman untuk berinteraksi dengan peserta didik lain maupun guru.

\section{Evaluasi Pembelajaran Keterampilan Berbicara Berbasis Teks Biografi di SMAN 8 Surakarta Kelas Inklusi X IPS 2 dan X IPS 5}

Evaluasi pembelajaran teks biografi yang digunakan oleh guru mata pelajaran untuk peserta didik reguler dan berkebutuhan khusus adalah sama. Para peserta didik reguler dan berkebutuhan khusus diberikan soal remidiasi sejumlah 10 soal yang kemudian dikerjakan dan dikumpulkan kepada guru. Yang membedakan antara peserta didik reguler dan berkebutuhan khusus adalah bobot soalnya.

Perbedaan lainnya dalam mengerjakan soal-soal remidiasi adalah terletak pada media yang digunakan oleh peserta didik. Sama seperti peserta didik reguler pada umumnya, mereka mengerjakan soal-soal remidiasi pada selembar kertas yang sudah disiapkan. Kemudian dikumpulkan kepada guru. Adapun peserta didik berkebutuhan khusus dengan hambatan berbicara dan juga tunadaksa mengerjakan dengan media laptop. Yang kemudian dikumpulkan melalui surat elektronik (email).

Tugas remidi yang sudah dikumpulkan kepada guru mata pelajaran, selanjutnya diolah dan dimasukkan ke dalam lembar penilaian yang sudah disiapkan oleh guru mata pelajaran. Perlakuan yang dilakukan oleh guru mata pelajaran dalam pemberian evaluasi tidak membedakan antara peserta didik reguler dan peserta didik berkebutuhan khusus. Dalam memberikan evaluasi bagi peserta didik berkebutuhan khusus, guru sudah melakukannya dengan baik dengan menyesuaikan kebutuhan peserta didik berkebutuhan khusus. Hal tersebut diungkapkan Maftuhatin dalam jurnalnya (Volume 6, Nomor 2, Oktober 2014) mengemukakan pendapat bahwa layanan dalam pendidikan inklusif harus memperhatikan hasil identifikasi dan asesmen anak berkebutuhan khusus. Berdasarkan hasil identifikasi dan asesmen 
tersebut dikembangkan berbagai kemungkinan alternatif program layanan yang sesuai dengan kebutuhan anak. Layanan alternatif yang dimaksud adalah layanan pendidikan yang disesuaikan dengan kemampuannya yang dalam hal ini anak berkebutuhan khusus belajar bersama di dalam komunitas kelas yang beragam di bawah bimbingan bersosialisasi dan hidup dalam lingkungan nyata.

Pelaksanaan evaluasi pembelajaran yang dilakukan oleh guru sudah baik dan terstruktur. Hal tersebut sesuai dengan tujuan evaluasi pembelajaran menurut Depdiknas (2003: 6) yang mengemukakan bahwa tujuan evaluasi pembelajaran adalah untuk melihat produktivitas dan efektivitas kegiatan belajar-mengajar, memperbaiki serta menyempurnakan kegiatan guru, mengembangkan program belajarmengajar, mengetahui kesulitan-kesulitan yang dihadapi peserta didik, dan menempatkan peserta didik dalam situasi belajar mengajar yang tepat sesuai dengan kemampuannya.

\section{Kendala dan Upaya dalam Pembelajaran Keterampilan Berbicara Berbasis Teks Biografi di Kelas Inklusi $X$ IPS 2 dan X IPS 5 SMAN 8 Surakarta}

Berdasarkan observasi dan hasil wawancara, ditemukan beberapa kendala yang menggangu pelaksanaan pembelajaran teks biografi di SMAN 8 Surakarta. Kendala-kendala tersebut timbul dari dalam diri peserta didik dan guru. Kendala-kendala tersebut antara lain:

\section{Guru dan Peserta Didik Reguler Kurang Memahami Bahasa Isyarat}

Komunikasi yang baik sangat dibutuhkan pada setiap kegiatan pembelajaran, termasuk pembelajaran teks biografi di kelas inklusi. Komunikasi yang terjalin akan membuat kelancaran pembelajaran semakin mudah diraih, peserta didik dapat dengan baik memahami materi pembelajaran dari guru, dan peserta didik juga dapat saling menggali informasi dengan berkomunikasi antara guru dan peserta didik.

Kelas inklusi yang menggabungkan peserta didik reguler dengan peserta didik berkebutuhan khusus, mengharuskan peserta didik dan guru saling memahami kondisi termasuk komunikasi. Adanya peserta didik berkebutuhan khusus tunadaksa wicara memberikan dampak bagi peserta didik reguler dan guru agar mampu memahami ujaran yang disampaikan oleh peserta didik berkebutuhan khusus.

Keadaan semacam ini mengakibatkan proses pembelajaran terkadang harus terhambat, guru harus mengulangi materi secara personal kepada peserta didik berkebutuhan khusus, yang kadang materi yang dijelaskan tidak terlalu rinci seperti penjabaran sebelumnya. Akibatnya, alokasi waktu yang direncanakan guru menjadi kurang dapat ditepati. Begitu pula peserta didik reguler menjadi canggung untuk berkomunikasi dan bekerja sama dengan peserta didik berkebutuhan khusus.

Upaya telah dilakukan oleh guru dan peserta didik untuk menanggulangi kendala pemahaman bahasa isyarat. Pihak guru koordinator inklusi di SMAN 8 Surakarta telah membuat pelatihan bahasa isyarat bagi guru dan terbuka untuk peserta didik agar mampu memahami bahasa isyarat dengan baik. Peserta didik reguler yang dapat berbahasa isyarat hanya terdapat satu orang, yang menjadi pusat bantuan bagi peserta didik lain berkomunikasi. Hal ini sebaiknya perlu diperhatikan agar komunikasi yang terjadi saat pelaksanaan pembelajaran apresiasi sastra di kelas inklusi dapat berjalan dengan baik dan lancar.

\section{Tidak Ada Guru Pendamping Khusus}

Di kelas X Animasi dan X Seni Lukis terdapat satu tenaga pendidik, yakni guru mata pelajaran yang mengajar di kelas inklusi. Guru mata pelajaran mengampu peserta didik reguler maupun peserta didik berkebutuhan khusus tanpa 
ada pendampingan dengan guru pendamping khusus.

Di SMAN 8 Surakarta terdapat guru koordinator inklusi, namun tidak ada guru pendamping khusus. Koordinasi dalam pembelajaran inklusi hanya terjadi antara guru koordinator inklusi dan guru mata pelajaran. Hal ini yang mengakibatkan tugas guru mata pelajaran menjadi lebih berat untuk mengampu peserta didik di kelas inklusi. Selain itu, juga perlu mengadakan pendekatan secara personal untuk pemenuhan kebutuhan peserta didik berkebutuhan khusus agar kegiatan pembelaran tetap berjalan dengan baik dan lancar.

Upaya yang dilakukan oleh SMAN 8 Surakarta dalam memfasilitasi peserta didik berkebutuhan khusus adalah dengan memberikan jam tambahan atau les pribadi di ruangan yang berbeda dengan peserta didik reguler. Dengan upaya tersebut, diharapkan peserta didik berkebutuhan khusus dapat belajar dengan lebih santai dan tetap percaya diri.

\section{Peserta Didik Berkebutuhan Khusus Cenderung Tertutup}

Guru mata pelajaran tidak memiliki keahlian khusus yang mampu memahami kondisi peserta didik berkebutuhan khusus secara mendalam. Pendampingan khusus perlu diberikan bagi peserta didik berkebutuhan khusus di kelas X IPS 2 dan $X$ IPS 5. Kendala ini menghambat bagi peserta didik reguler. Peserta didik berkebutuhan khusus terkadang bersikap individu dan sulit untuk diajak bekerja sama. Akibatnya, pengumpulan informasi dengan diskusi tidak dapat dilaksanakan bagi peserta didik berkebutuhan khusus.

Guru mata pelajaran hanya mampu membuat upaya dengan cara pendekatan personal seperti halnya memberi konseling bagi peserta didik berkebutuhan khusus. Pendekatan secara personal ini terjadi pada saat pembelajaran berlangsung. Jika sudah seperti ini, guru menghentikan pelajaran, memberikan pengertian kepada peserta didik berkebutuhan khusus secara personal. Hal ini mengakibatkan hambatan bagi guru untuk mengalokasikan waktu pembelajaran dengan tepat.

\section{Keterbatasan Media Gambar sebagai Sarana Proses Pembelajaran}

Media gambar dalam pembelajaran keterampilan berbicara berbasis teks biografi merupakan salah satu upaya yang dilakukan guru untuk merangsang minat belajar bagi peserta didik reguler maupun peserta didik berkebutuhan khusus. Penggunaan media gambar yang digunakan oleh guru sebatas gambar yang tertera pada buku teks. Guru mata pelajaran bahasa Indonesia dalam hal ini tidak menyediakan sejumlah gambar sebagai media pembelajaran.

\section{SIMPULAN DAN SARAN}

Berdasarkan hasil temuan penelitian dan pembahasan mengenai pembelajaran teks biografi di SMAN 8 Surakarta maka dapat disimpulkan sebagai berikut.

Penyusunan RPP mengacu silabus dan berpedoman pada Permendikbud Nomor 22 Tahun 2016 yang berisi jenis, istilah, dan sistematika komponen RPP menurut Kurikulum 2013. Perencanaan yang dirancang oleh guru sebagai sebuah kesiapan guru dalam melakukan pembelajaran telah dilakukan dengan memperhatikan siswa berkebutuhan

khusus. Perencanaan secara tertulis telah dilakukan dengan baik, perencanaan mengenai pengaturan tempat duduk, pengondisian kelas tidak tertulis secara rinci di rencana pelaksanaan pembelajaran.

Pelaksanaan pembelajaran teks biografi di kelas inklusi SMAN 8 Surakarta telah dilakukan berdasarkan kurikulum 2013. Peserta didik berkebutuhan khusus dan peserta didik reguler belajar bersama dalam satu ruang

kelas yang sama tanpa ada pembedaan diskriminatif. Guru melakukan bimbingan kepada siswa dengan membuat kelompok kecil guna menemukan hal-hal yang dapat diteladani dari tokoh dalam teks biografi. Selain itu, berdasarkan penelitian yang 
telah dilakukan di SMAN 8 Surakarta, model pembelajaran inklusi yang dilakukan adalah model inklusi penuh, yakni model pendidikan inklusi yang menggabungkan peserta didik reguler dan peserta didik berkebutuhan khusus.

Teknik evaluasi yang dilakukan oleh guru berupa pemberian soal-soal remidi sebanyak sepuluh soal yang ditujukan untuk peserta didik reguler dan berkebutuhan khusus. Perbedaan evaluasi oleh guru terletak pada media yang digunakan oleh peserta didik dalam mengerjakan soal-soal remidi. Peserta didik reguler mengerjakan pada kertas yang sudah disediakan, sedangkan peserta didik berkebutuhan khusus mengerjakan pada laptop yang kemudian dikumpulkan melalui surat elektronik (email) atau menggunakan flashdisk.

\section{REFERENSI}

Affandi, Muhammad, dkk. (2013). Model dan Metode Pembelajaran di Sekolah. Semarang: UNISSULA PRESS.

Affandi, Muhammad. (2009). Perencanaan Pembelajaran Pendidikan Dasar. Khazanah Pendidikan, 1 (2).

Arifin, Zainal. (2010). Evaluasi Pembelajaran (Teori dan Praktik). Bandung: Universitas Pendidikan Indoonesia.

Cahyadwiantari, Dwi. (2017). Strategi Guru dalam Pembelajaran Membaca Teks Biografi pada Siswa Kelas VIII SMP Negeri 2 Singaraja. E-Journal Jurusan Pendidikan Bahasa dan Sastra Indonesia, Undiksha, 7 (2).

Daryanto dan Dwicahyono, Aris. (2014). Pengembangan Perangkat Pembelajaran (Silabus RPP, PHB, Bahan Ajar). Yogyakarta: Gava Media.

Ilahi, Mohammad Takdir. (2013). Pendidikan Inklusif: Konsep dan
Kendala yang dihadapi guru selama pembelajaran teks biografi di kelas X IPS 2 dan X IPS 5 SMAN 8 Surakarta adalah kurangnya pemahaman mengenai bahasa isyarat untuk berkomunikasi dengan siswa berkebutuhan khusus dengan tunadaksa wicara, dalam pembelajaran tidak ada guru pendamping khusus bagi siswa berkebutuhan khusus, terdapat siswa berkebutuhan khusus yang cenderung menutup diri dan tidak mudah untuk bekerja sama dengan siswa reguler. Upaya yang dilakukan guru untuk mengatasi masalah adalah dengan melakukan pelatihan bahasa isyarat, melakukan pendekatan secara personal kepada peserta didik berkebutuhan khusus, dan memfasilitasi jam tambahan atau les pribadi bagi peserta didik berkebutuhan khusus yang merupakan program dari guru koordinator inklusi.

Aplikasi. Yogyakarta: Ar-Ruzz Media.

Indrastoeti, Jenny. (2012). Pengembangan Assesmen Pembelajaran Sekolah Dasar. Surakarta: UNS Press.

Maftuhatin, Lilik. (2014). Evaluasi Pembelajaran Anak Berkebutuhan Khusus (ABK) di Kelas Inklusif Di SD Plus Darul Ulum Jombang. Jurnal Studi Islam, 5 (2).

Mahesa, Gallan Berkah, dkk. (2013). Perencanaan Pembelajaran Oleh Guru di SMP Negeri 23 Padang dalam Setting Inklusi. Jurnal Ilmiah Pendidikan Khusus, 2 (3).

Mudjito, dkk. (2012). Pendidikan Inklusif. Jakarta: Baduose Media.

Niron, Maria Dominika. (2009). Pengembangan Silabus dan Rencana Pelaksanaan Pembelajaran dalam KTSP. Yogyakarta: PSG Rayon 11 UNY.

Nugroho, Agung. (2016). Model dan Strategi Pembelajaran Anak Berkebutuhan Khusus dalam Setting 
Pendidikan Inklusi. Jurnal Pendidikan Dasar PerKhasa, 2 (2).

Nurhayati. (2008). Berbagai Strategi Pembelajaran Bahasa Dapat Meningkatkan Kemampuan Berbahasa Siswa. Jurnal Bahasa \& Sastra, 9 (2).

Peraturan Menteri Pendidikan dan Kebudayaan Nomor 22 Tahun 2016 Tentang Standar Proses Pendidikan Dasar dan Menengah.

Permendiknas Nomor 41 Tahun 2007. Standar Proses untuk Satuan Pendidikan Dasar dan Menengah. Jakarta.

Putra, Listya Buana, dkk. (2016). "Implementasi Kurikulum 2013 pada Pembelajaran Menulis Teks Cerita Ulang Biografi (Studi Kasus di SMA Negeri 1 Surakarta)". BASASTRA, 4 (1).

Rahardjo, Mudjia. (2007). Bahasa Sebagai Alat Komunikasi Publik dan Pembangunan Wacana. Lingua, 2 (1).

Rianto, Milan. (2006). Pendekatan, Strategi, dan Metode Pembelajaran. Direktorat Jenderal Peningkatan Mutu Pendidikan dan Tenaga Kependidikan.

Sanjaya, Wina. (2009). Strategi Pembelajaran Berorientasi Standar Proses Pendidikan. Jakarta: Kencana.

Setyawanto, Agung, dkk. (2012). Rencana Pelaksanaan Pembelajaran (RPP) Guru Bahasa Indonesia Tingkat SMP di Kota Malang. Malang: Universitas Negeri Malang.
Sugiyanto. (2009). Model-model Pembelajaran Inovatif. Surakarta: Panitia Sertifikasi Guru (PSG) Rayon 13 FKIP UNS.

Suwandi, Sarwiji. (2009). Model Assesmen dalam Pembelajaran. Surakarta: Panitia Sertifikasi Guru (PSG) Rayon 13 FKIP UNS.

Tarnoto, Nissa. (2016). PermasalahanPermasalahan yang Dihadapi Sekolah Penyelenggara Pendidikan Inklusi Pada Tingkat SD. Humanitas, 13 (1).

Teguh Prastyo, Angga. (2012). Merancang Perencanaan Pembelajaran Berbasis Pendidikan Karakter. Jurnal ElHikmah Fakultas Tarbiyah UIN Malang, 9 (2).

Trimo. (2012). "Manajemen Sekolah Penyelenggara Pendidikan Inklusif: Kajian Aplikatif Pentingnya Menghargai Keberagaman Bagi Anak-Anak Berkebutuhan Khusus". $J M P, 1$ (2).

Vina Mulya, Septi. (2017). Pembelajaran Menulis Teks Biografi Siswa Kelas VIII SMP Global Madani Bandar Lampung. Jurnal Kata.

Winaya, Kadek I, dkk. (2015). "Analisis Rencana Pelaksanaan Pembelajaran Menurut Kurikulum 2013 Kelas IV SD No. 4 Banyuasri”. E-Journal PGSD Universitas Pendidikan Ganesha, 3 (1).

Yusuf, M \& Choiri, S. (2012). Pendidikan Kompensatoris Anak Berkebutuhan Khusus (ABK). Makassar: PSG Rayon 124 Universitas Negeri Makassar 